\title{
BRAGUE, Rémi. Le règne de l'homme: genèse et échec du projet moderne. Paris: Gallimard, 2015. 416 p. (Collection L'Esprit de la cité).
}

Elton Moreira Quadros ${ }^{*}$

*Universidade do Estado da Bahia - Paulo Afonso, BA, Brasil eltonquadros@yahoo.com.br 
Publicado na França em 2015, o livro Le règne de l'homme: genèse et échec du projet moderne ("O reino do homem: gênese e malogro do projeto moderno") do professor e filósofo Rémi Brague, realiza uma contundente crítica aos valores modernos que ainda marcam o nosso tempo, quer do ponto de vista das questões relacionadas à forma como o conhecimento é estruturado, quer como nos organizamos socialmente e, especialmente, tendo em vista a antropologia desenvolvida a partir do projeto moderno.

Culminando uma trilogia iniciada com La sagesse du monde ("A sabedoria do mundo") (Brague, 2002), que tem a Antiguidade como foco e que é seguido de La loi de Dieu ("A lei de Deus") (Brague, 2005), cujo cerne está na investigação sobre a Idade Média, em Le règne de l'homme, Brague lança um olhar arguto e pouco usual sobre a gênese do projeto moderno atingindo aquilo que o autor francês considera seu ponto de decadência e malogro. Com isso, temos encerrado um caminho que indica um slogan que veio sendo gestado no desenvolvimento dos livros anteriores: "[A] ideia de um 'reinado do homem', meu título, é o slogan declarado ou implícito. Além do paralelismo desejado com os títulos dos dois livros anteriores, suas duas pesquisas levaram a essa ideia" (p. 7, tradução minha). Apesar da crítica contundente, Brague, que possui uma visão de mundo anunciadamente cristã, não compreende a modernidade de um ponto de vista reacionário ou mesmo antimoderno.

Sua visão se centra no problema que afirma que houve na modernidade uma tentativa de fundar um humanismo "puro", ou seja, sem que mais nada delimitasse a atuação humana, quer o divino, como a que os medievais estavam ligados, quer a natureza, que, na modernidade, desejou ser dominada, submissa. Isso acabou por nos levar a um caminho em que o sentido do humano muitas vezes foi perdido e, mesmo, em que a tentativa de ultrapassar a natureza nos causou efetivos riscos enquanto habitantes desse mundo.

Brague compreende a noção de projeto dentro de uma definição bem estrita, isto é, uma proposta nova que busca a autonomia do sujeito tendo em vista o progresso. No caso da modernidade, tinha-se uma ideia de sua origem até o seu declínio de um progresso sem fim, em que a humanidade teria que seguir sempre e cada vez mais em direção a uma evolução do conhecimento e, consequentemente, da tecnologia. Essa foi uma das grandes promessas do projeto moderno e, desconfiamos, sua maior "garota-propaganda". 
Nesse projeto, o homem passa a se considerar o "criador" não só de coisas, mas, em alguma medida, de sua própria humanidade, tanto que o passado imediato passa a ser considerado um período de "trevas". O projeto moderno encontra em Descartes um pensador que deseja estabelecer uma certeza que seria a grande fiadora do pensamento humano como senhor e possuidor da natureza.

Grande parte do pensamento moderno está identificada com esse ideal em que o pensamento humano poderá dar respostas totais e cabais a respeito do mundo tendo em vista a ideia de progresso alcançado através da razão instrumental. Brague será um crítico desse projeto e de sua pretensão:

Então eu tive que ter uma visão global do projeto moderno. E admitir o que me faz tremer, a saber, que este projeto está fadado ao fracasso, ou até mesmo, que já falhou em princípio. Privar o humano de todo contexto leva a destruí-lo. Mostrei menos criticando o projeto moderno do que mostrando como a lógica interna de seu desenvolvimento, que é suficiente dizer, leva a uma dialética autodestrutiva. (p. 7-8, tradução minha).

Ele acredita que somos ainda hoje herdeiros desse projeto marcado por um início de um grande entusiasmo esperançoso que terá como seus marcos o racionalismo e/ou empirismo, entre outros, com o consequente ápice advindo com o positivismo, que acreditava que o maior desenvolvimento humano estaria numa espécie de era do conhecimento científico.

O projeto moderno possui uma diversidade de influências que o geram e o impulsionam. Brague chama a atenção para as fontes gnósticas do Renascimento em que há um efetivo peso dado ao conhecimento. Outro ponto apontado por Brague é a Reforma Protestante, fruto nascido na modernidade. O autor francês acredita que há uma ênfase dada no ideário protestante em que se aposta que a graça divina pode corrigir a natureza humana. Se, no primeiro aspecto, temos a ênfase na questão epistemológica, no segundo, temos uma ênfase na moral.

O livro está dividido em três partes: na primeira, ainda na esteira das duas obras iniciais da trilogia, Brague parte da Antiguidade e da Idade Média para demarcar o espaço de formação do projeto moderno, especialmente, a dominação da natureza e a consequente supervalorização do homem. 
A segunda parte abordará mais diretamente a mudança, comandada por Bacon, na concepção do conhecimento. Se antes o conhecimento estava relacionado com a contemplação, na modernidade, ele passa a ser considerado instrumentalmente, isto é, agora ele interessará à atividade produtiva. Aqui temos os avanços científicos e a própria Revolução Industrial no centro dessa mudança do valor e objetivo do conhecimento.

Por fim, na terceira parte, temos a narração do malogro da modernidade apontado desde o início por Brague. Nesse ponto, temos aquilo que será entendido, utilizando as palavras do poeta Charles Peguy, como o caráter "parasitário da modernidade" (p. 190, tradução minha). De um lado, temos exposto um conjunto grande de características da modernidade, tais como a desvalorização da natureza e a supervalorização da indústria e da tecnologia, o avanço do capitalismo, o abandono dos valores religiosos, uma visão de mundo que não deseja mais conhecer e sim dominar as coisas e o mundo, o desenvolvimento de um ideal em que o homem é considerado um ser autônomo e autossuficiente. Do outro, Brague também nos coloca como herdeiros de ideias que são consequência do projeto moderno, tais como racionalização da vida humana ou coisas ainda mais graves como eugenia, desvalorização (mercantilização) da vida humana, entre outros.

Se, com Descartes, começou a pretensão do projeto moderno de estabelecer o homem como dominador do mundo, será Nietzsche quem afirmará que o homem deve ser superado, já que só conseguiu conquistar o niilismo. O projeto moderno demonstrou-se, ao longo de seu desenvolvimento, ser uma pretensão impossível, daí acabar gerando angústia, desilusão, fracassos que nos farão, segundo Brague, aderir, no início do século $\mathrm{XX}$, às chamadas propostas totalitaristas do ponto de vista político ou niilistas do ponto de vista antropológico.

Brague é conhecido com um dos mais eruditos historiadores das ideias na atualidade, e isso é demonstrado nesse livro e em toda a trilogia, em que o tempo todo o autor recorre a citações diretas de pensadores e literatos, como ele mesmo explica, para que o leitor não pense ser um exagero somente dos seus argumentos. O projeto moderno, segundo Brague, nos leva a uma espécie de desespero niilista. Apesar de um recorte que não distingue inteiramente aquilo que constitui o projeto moderno que fracassa e aquilo que, na modernidade, também apresenta bons frutos, há, efetivamente, na modernidade, um caminho em que se afirmam posições relativas a uma visão reducionista 
da condição humana, a qual é também apontada por inúmeros outros autores; para citar alguns, Bauman, Hannah Arendt, Freud, Latour, Habermas e MacIntyre.

Será que algum dia sairemos dessa aporia? Isso parece difícil de ter claro hoje, mas uma coisa parece que nos acompanhará por muito tempo: a modernidade não foi ultrapassada por nós e, talvez, dificilmente seja: estamos (ainda ou sempre?) enredados nesse labirinto. E se esse labirinto nos domina tanto é, certamente, por conta de que ainda estamos verdadeiramente enredados em seus "frutos".

\section{Referências}

BRAGUE, R. La sagesse du monde: histoire de l'expérience humaine de l'univers. Paris: Le Livre de Poche, 2002. (Collection Biblio Essais).

BRAGUE, R. La loi de Dieu: histoire philosophique d'une alliance. Paris: Gallimard, 2005. 